\title{
The Unofficial Vicereine of Río de la Plata: a Trans-Imperial Mediator in the Global War, 1797-1810
}

\author{
Deborah Besseghini ${ }^{\mathrm{a}}$ \\ ${ }^{a}$ Università degli Studi di Milano \\ $\bowtie$ deborahbesseghini@gmail.com
}

\begin{abstract}
This article traces the story of one of the most significant unofficial mediators in the context of the imperial reconfiguration of the Atlantic World between the late 18th and early 19th centuries. The protagonist was a woman of many identities, loyalties, experiences, and allegiances, who stood at the center of business and family networks of global dimension. Of French descent, married to an Irishman, and naturalized a Spanish subject in Buenos Aires, "Anita" Périchon was able to strike a balance between British and Hispanic-American imperial and personal interests. Wellknown in Argentina as the mistress of Viceroy Liniers, this article focuses on the role she played in the system of corruption that allowed British merchants to conduct business in Río de la Plata between the June 1808 alliance of Britain and anti-French Spain and the legal opening of direct trade with the British in Buenos Aires in November 1809.
\end{abstract}

Article History: Received: May 22019 / Revised: 10 July 2019 / Accepted: 20 July 2019

Keywords: Economic Transitions; Empires; Business History; Latin America; Revolution.

JEL Classification: N4, N8, N86

\section{Acknowledgements}

This article is the result of research for a chapter of my doctoral thesis which I then revised and refined on the occasion of its presentation at the conference "Dono, controdono e corruzione: ricerche storiche e dialogo interdisciplinare", organized by Gianluca Cuniberti of the Università degli Studi in Turin in December of 2015 at the Luigi Einaudi Foundation. I thank all the participants in this convention for their comments. I would also like to thank Julia Nitz and Joanne Paisana, together with all the colleagues who helped me further reflect on the story of Anita O'Gorman in the context of the Intercontinental Crosscurrents Network conference, held in Braga in November of 2016. Additional thanks go to Edoardo Tortarolo, Cristina Mazzeo and to all the colleagues who read and made comments on the earlier versions of this text, as well as to the anonymous readers of this journal. The responsibility for any mistakes is mine alone. 
Marie Anne Périchon de Vandeuil (1775-1847), known as "Anita" or "la Perichona," is a protagonist of the historical-mythical narrative associated with the birth of the Argentinian nation. She was the mistress of Viceroy Jacques (aka Santiago) de Liniers (1753-1810), hero of the reconquest of Buenos Aires at the time of the British invasion of 1806, an event that is traditionally linked to the dawn of Argentinian independence. ${ }^{1}$ Shortly after her death, Anita's fame was further increased by the amorous elopement of her granddaughter, Camila O'Gorman (1825-1848), with the priest Ladislao Gutiérrez, which triggered a scandal magnified by the opponents of the regime of Juan Manuel de Rosas, especially when Camila was executed. Poems, films, and novels have been dedicated to the love lives of both women. ${ }^{2}$ Less well-known is Marie Anne's role in the economic history of Hispanic America.

Direct British trade in Buenos Aires was informally opened in good measure through Anita, who, on the eve of the independence process from Spain, became almost an unofficial vicereine. Merchants paid her a voluntary contribution, a kind of gift or bribe, for permission to unload their goods during the normative Limbo, which began with the June 1808 alliance between Britain and anti-French Spain and ended with the legal opening of direct trade with the British in Buenos Aires in November 1809. Anita's influence was likely due to the Viceroy's decision to use her as a mediator with British merchants in an unprecedented and politically sensitive situation, but also to her family and personal links to global merchants who were active in the context of the trade and financial changes caused by the Napoleonic Wars.

Anne was born in 1775 , on the island of Réunion. Her father, a nobleman named Étienne Périchon (1746-?), was an official of the French East India Company. In Port Louis, in 1792, she married Thomas O'Gorman (1760-1816?), an Irish officer in the French service, with whom she had three children: Adolphe (Camila's father), Thomas, and María, born in Montevideo in 1797. In this year, as Étienne Périchon testified, the Périchon-O'Gorman family had moved to Buenos Aires in order to live in a Catholic country. Michael Gorman (1749-1819), Thomas O'Gorman's uncle, an inoculation expert and Protomedico, i.e. the officer in charge of public health - a position he had obtained despite suspicions of being a British spy — was already living there. ${ }^{3}$

Upon arrival, Thomas applied for Spanish naturalization for himself and his family and requested permits to undertake activities such as importing hundreds of African slaves for agricultural enterprises in Paraguay and hiring Irish experts in meat salting. ${ }^{4}$ Around the same time, William White (1770-1842), an American merchant with whom the Périchon-O'Gorman family had previously established ties and to whom they would remain associated, ${ }^{5}$ also arrived in Buenos Aires. In the East Indies White had been in business with Home Popham (1762-1820),

\footnotetext{
${ }^{1}$ Mitre (1887).

${ }^{2}$ Some crucial sequences in María Luisa Bemberg's film Camila (1984) are dedicated to Anita. In literature, we can mention Enrique Molina's story Una sombra donde sueña Camila O'Gorman (1973).

${ }^{3}$ Méndez (2008), 100; Fannin (2018), 96. Archivo General de las Indias [hereafter, AGI] Estado 80, n. 58, Olaguer Feliú to Francisco de Saavedra, December 29, 1798.

${ }^{4}$ AGI, Estado, 78, N. 5, O'Gorman to the Prince of Peace [Godoy], Montevideo, 1797; Miguel Cayetano Soler to Mariano Luis de Urquijo, July 2, 1799. For a similar proposal by Manuel Belgrano, see Brilli (2016), 122.

${ }^{5}$ Archivo General de la Nación [hereafter AGN], Ledger 438, Miguel Gorman to Ana O'Gorman, December 9, 1809.
} 
the naval commander who in 1806 planned and conducted the attack that resulted in Britain's brief occupation of Buenos Aires. It is believed that White sent Popham information about Buenos Aires before the invasion, ${ }^{6}$ during which Thomas O'Gorman left Río de la Plata for good and Anita became Liniers's mistress.

The case of Anita is key for discussing the role of corruption as a vector of change during the late years of the Spanish Empire in the Americas. Informal practices and networks can be a driving force and a vehicle for subverting decaying political and economic structures. Indeed, quoting Fernand Braudel, the slow revolution at the base of capitalism affirmed itself in the "règne de la débrouille et du droit du plus fort" through that contre-marché which de-structured the norms of medieval trade and provided key practices and means for surmounting it. ${ }^{7}$ This article assesses the breakdown of the rules underlying the Spanish trade system in a particular context, where they became object of an obligate negotiation with official and unofficial agents from the emerging hegemonic power, Great Britain. It is key to consider the balance of power between Hispanic-American colonies and Britain during the war against Napoleon and the civil war in Spain, as well as the reasons why in Río de la Plata there was no viable alternative to an alliance with Great Britain, mistress of the seas.

The merchant Alexander Graves described Anita as the person in Buenos Aires who brought "the old system of corruption and venality in the public departments to a greater height than had ever before been known." 8 In short, it was taken for granted that the Spanish administration was traditionally corrupt and that Anita had just stretched it to the limit. This opinion derived, not just from a traditional negative prejudice against the Hispanic world, ${ }^{9}$ but also from Britain's long-standing smuggling experience in the colonies. Yet, the Spanish monarchy could itself benefit from tolerance for such activities, insofar as illicit trade contributed to general economic growth and greater wealth strengthened the loyalty of the elite. Liberalizing trade would have favored the economic colonization of its territories by subjects of rival powers. Rules can sometimes be neither fully respected nor radically changed. And corruption also helped to harmonize interests between the mother country and the colonies in other empires - including, not least, the British.

Despite a sort of leyenda negra in the economic field, at the time widespread in Britain, which saw Spain as incapable of exploiting the vast resources of the Americas (and traceable even in some passages by Adam Smith against the colonial system and monopoly), ${ }^{10}$ the tendency toward liberalizing trade in Spanish America had been established since the mid-18th century. It had become a predominant trend within the Empire. The modernity of new economic ideas, including physiocratic theories, went hand in hand, in practice and in all empires, with the need to protect the system from rivals.

\footnotetext{
${ }^{6}$ Roberts (1938), 36, 99, 104-5; Newitt (2010), 154-5.

${ }^{7}$ Braudel (1979), 197.

${ }^{8}$ The National Archives [hereafter TNA] Foreign Office [hereafter FO] 63/85, Graves to Lord Strangford, July $13,1810$.

${ }^{9}$ It is worth mentioning here Carlos Contreras's 2013 review of Alfonso Quiroz's posthumous book on corruption in Peru, in which the author underlines a persistent "anti-Latin" attitude in contemporary U.S. diplomatic sources, which does not take into account the "costumbres de reciprocidad tradicional" defining many forms of such tradition as corruption (Contreras, 2013, 214).

${ }^{10}$ Paquette (2011).
} 
The Spanish monarchy guaranteed broad economic opportunities. In the 1760s, Cuba became the first region to benefit from certain forms of comercio libre; and a 1778 decree allowed direct exchange between the many puertos habilitados, i.e. ports authorized for trade in America and Spain. New and dynamic Hispanic global merchants, such as the Andalusian Tomás Antonio Romero and the porteño Pedro Duval, whose operations extended from the Baltic to the United States, and from Africa to Spain and Latin America, slowly began to replace the old Cádiz monopolists. ${ }^{11}$ The comercio de negros, inaugurated in 1789 , allowed foreigners to transport slaves into the colonies and export frutos del pais on their own ships. These practices fostered smuggling. This was also denounced in a report sent to Madrid by the Viceroy of Río de la Plata, Joaquín del Pino (1729-1804), and similar complaints came almost at the same time from the Intendant of Caracas. ${ }^{12}$ The greatest fears were related to British contraband.

British naval attacks and blockades during the wars against France, after the 1796 FrancoSpanish alliance, resulted the following year in the royal decree on comercio de neutrales, a practice already partially implemented during the American Revolution, which permitted the use of neutral ships and allowed direct trade between Spain and non-enemy ports. The repeal of the norm in 1799 was largely ignored in Hispanic America and the system continued through the issuance of licenses. ${ }^{13}$ In 1800, for example, Thomas O'Gorman obtained the support of the Contador de las reales cajas of Buenos Aires, Antonio Carrasco, in applying for, and obtaining, a license to conduct trade on neutral ships between South America and the ports of Philadelphia and Hamburg. ${ }^{14}$ Spain's enemies, the British, could not normally trade directly with the Spanish colonies. However, imports of British and Asian products through Britain flourished in Hispanic America, thanks to the intermediation of merchants of various nationalities and the use of neutral ships, especially from the United States. In the 1790s, indirect and illegal trade with Hispanic America became of great strategic interest to London. ${ }^{15}$

In order to supply a distressed colony and collect customs revenues at a time of severe disturbances in maritime trade, or eventually to participate or involve members of his own network in a lucrative deal, a senior Spanish official could turn a blind eye to British smuggling, or cover up otherwise illegal activities with special licenses. Calling this corruption is too simplistic: the consequences of continuous war on trade practically imposed this set of effective practices. Moreover, the legal participation of the British in Hispanic-American trade was exceptionally possible through licenses issued by colonial and central authorities. ${ }^{16}$

In a new phase of the war against Spain, especially since 1804 and later after Trafalgar, Britain also managed to intercept, through the so-called Bullion Contracts, part of the gold and silver from Hispanic America destined to pay Spain's war subsidies to Napoleon. Bullion Contracts were special agreements established by the Board of Trade and the Treasury with companies holding Spanish licenses to trade with the colonies, such as the Hope/Baring cartel, Gorman

\footnotetext{
${ }^{11}$ Galmarini (1980); Heredia (1986); Cooney (1986), 32.

${ }^{12}$ Heredia (1986), 40-42; Pearce (2007), 176, 200.

${ }^{13}$ Cooney (1986); Pearce (2007); Stein and Stein (2009).

${ }^{14}$ AGI, Estado, 79, N. 19, September 12, 1800; September 14, 1801; Cooney (1989), 512, 518; Cooney (2004).

${ }^{15}$ e.g. Cuenca-Esteban (2014), 65.

${ }^{16}$ Pearce (2007), 200.
} 
Brothers, and Gordon \& Murphy. This also created an incentive for British indirect trade with Hispanic America. ${ }^{17}$ It should be noted that in Britain the convertibility of the pound sterling had been suspended in an attempt to curb the outflow of precious metals during the war and that at times the Bank of England reserves were very scarce, ${ }^{18}$ so it was more necessary than ever to obtain Hispanic-American silver to support international trade and military spending in Europe.

Manuel de Sarratea (1774-1849) was a member of one of the most important families of Buenos Aires and brother-in-law of Liniers. ${ }^{19}$ As compensation for damages caused by Viceroy del Pino (who had hampered the delivery to Buenos Aires of shipments owned by his American associates), in 1805 he obtained from Manuel Sixto Espinosa, the director of the Caja de Consolidación in charge of financing royal debt also by transferring Church's liquid assets to the state, a license to import a substantial amount of silver from Peru. He could also export from Lisbon to Hispanic America goods bought in England - a rather complex business he later managed through agents of Menzies, White \& Co. (of John Menzies and Joseph White) ${ }^{20}$ Marten Buist reported that around the same time (1805) there was talk in London about the movements of a "Spaniard" named "Saratea." The latter was trying to obtain permits to export British goods to Lima, Buenos Aires, Caracas, and Veracruz, in exchange for silver to be obtained with Spanish documents and imported into England in association with Gordon \& Murphy. ${ }^{21}$

On November 24, 1806, Secretario de Hacienda Miguel Cayetano Soler communicated to the Captain-General of Chile that Thomas O'Gormam had obtained a license to send four shipments with goods of any kind and origin ("sin excepción alguna") from Lisbon or from Spanish ports to Valparaíso, Arica, Callao, and Lima in exchange for the transportation to Lima of paper and quicksilver. He could ship coins and colonial products from the Pacific coast of South America "al puerto de Europa que más le convenga." 22 In 1807, the Gorman Brothers firm, to which Thomas O'Gorman was linked by business and, it is understood, by kinship, obtained an additional British license to trade with the Pacific ports and to transport bullion and coins to England from Spanish America. From Lima they could export three million of pesos "on account of the Spanish government". ${ }^{23}$ Moreover, Gorman Brothers had a private agreement (as defined in the Foreign Office archives) with the British Treasury. ${ }^{24}$ We know that, since 1807, Thomas O'Gorman acted as agent for Gorman Brothers in Chile and Peru, and that in 1809 he was expected in Spain. ${ }^{25}$

\footnotetext{
${ }^{17}$ Jiménez (1988); Pearce (2007, 2009).

${ }^{18}$ Silberling (1919), 293.

${ }^{19} \mathrm{He}$ was the brother of Liniers's wife, Martina de Sarratea, who died in 1805 on her journey back from the territory of Misiones, where Liniers was governor.

${ }^{20}$ Heredia (1986), 55-70. On the collaboration between Espinosa and Soler, see Marichal (2007), 141.

${ }^{21}$ Buist (1974), 324 and 328.

${ }^{22}$ Archivo Nacional de Chile [hereafter ANC], Captanía General, Vol. 762, ff. 86-87.

${ }^{23}$ TNA FO 72/90, O'Gorman Brothers to Lord Bathurst, November 14, 1809.

${ }^{24}$ Ibid; Roberts (1938), 39.

${ }^{25}$ TNA FO 72/90, Charles T. O'Gorman to Gorman Brothers, October 23, 1809; Newitt (2010), 175. In addition to Thomas, the person responsible for the deal on behalf of the firm was Charles Thaddeus O'Gorman (1785-1853), who later became British consul in Mexico. There are elements suggesting that Thomas was a distant cousin of Charles, whose brother, Michael Arthur, one of the founders of Gorman Brothers, was the great-grandfather of
} 
Therefore, Anita and Viceroy Liniers, both French, were linked to merchants (Sarratea and O'Gorman) engaged in business projects aimed at transporting silver from Hispanic America to the Iberian Peninsula and to Britain, then Spain's enemy. It remains unknown whether they saw Britain as a bulwark against the revolutionary winds that had swept their country and caused a diaspora of noble families such as their own. Nor is it clear how they responded to the advent of the Napoleonic regime and the alliance between Spain and France. However, we do know that this alliance favored the career of Liniers, who, as a Frenchman, had been accused in the short period of enmity between Spain and France in the 1790s by Martín de Álzaga (1755-1812), a long-time rival of Liniers in politics and business, of conspiring against Spain. ${ }^{26}$

According to a reconstruction by Argentinian historian Carlos Roberts, who in turn attributed it to Ricardo Caillet-Bois, in 1804 William White drafted a project for the independence of Río de la Plata, together with Liniers and his brother, Count Jacques Louis (1749-1809), international merchant, slave trader, and entrepreneur. The project was to be delivered to British Prime Minister Pitt by White \& Murphy's correspondents in London. Unfortunately, it was not possible to verify whether this company had anything to do with Gordon \& Murphy and their agent in Veracruz, José White. ${ }^{27}$

During the expedition of Commodore Popham in July 1806, when British General William Carr Beresford (1768-1856) conquered Buenos Aires for the British crown (and the treasure held in the town was immediately sent to Britain), Liniers was the captain of the port. From outside the city, with the help of Juan Martín de Pueyrredón (1776-1850) and the contribution of Álzaga, he managed to organize the Spanish counterattack, which was successful. ${ }^{28}$

It was at this time that Anita became the mistress of Buenos Aires's new hero. According to some romanticized versions of the story, Anita helped Liniers to free the city, including by using her allure on Beresford. ${ }^{29}$ We know that the Périchons and William White were among the merchants with most ties to the British occupants. ${ }^{30}$ Anita lived openly with Liniers, who formally assumed the position of Viceroy in 1808. She became the first lady of the town and was soon known by the sobriquet "la Perichona" after her family name and for the assonance with la Perricholi; i.e., actress Micaela Villegas (1748-1819), who years before had been the mistress of the Viceroy of Peru, Manuel de Amat.

Liniers ruled the viceroyalty of Río de la Plata in the midst of the Spanish monarchy's worst crisis, during a global war that would soon lay the foundations for the disintegration of a large part of the Iberian empires in the Americas. In 1807, he fended off a second invasion attempt originated in nearby Montevideo, from where the British had in the meantime continued to engage in smuggling with Buenos Aires. Ventura Marcó del Pont, who was an agent of Thomas O'Gorman, had about this time started a direct trade of hide, tallow, and salted meat from Río de la Plata to London. ${ }^{31}$ Liniers and Martín de Sarratea, his father-in-law, an agent of the

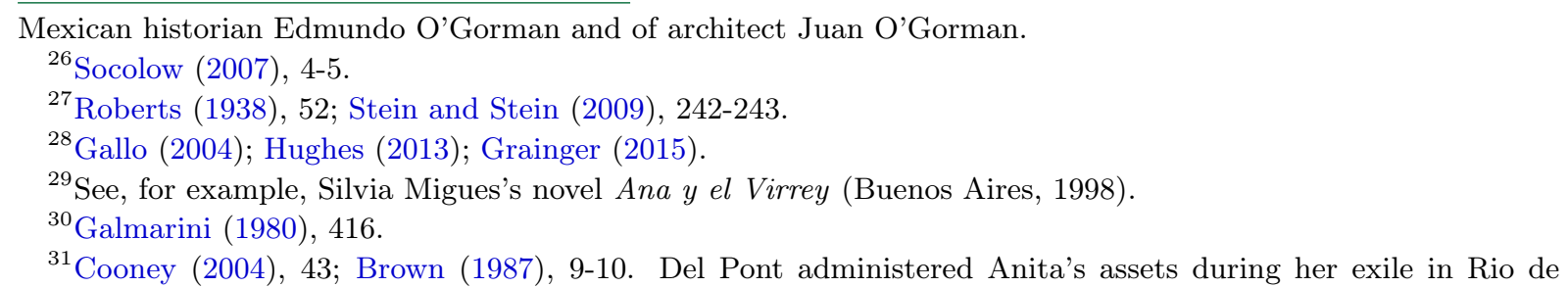


Philippine Company in Buenos Aires, ${ }^{32}$ also made good deals with the merchandise that the British had to sell quickly after their defeat and during their evacuation of both cities. ${ }^{33}$

The events of 1808 in Spain ushered in a phase of great uncertainty in South America. The abdications of the Bourbons, induced by Napoleon in Bayonne, generated the so-called Acefalia del imperio, since the colonies did not recognize Joseph Bonaparte as sovereign, while Ferdinand VII was under the custody of the French. With the emergence of resistance against "the usurper," Britain became an ally of the Spanish anti-French government and intensified pressure for direct trade with Hispanic America, which remained loyal to the Bourbons. On December 22, 1807, President Jefferson established a U.S. embargo against British and French trade as a reaction to recurrent episodes of violation of U.S. neutrality, especially by Britain. This closed the main channel through which British goods had been making their way to Hispanic America for years, and Britain did not intend to miss the opportunity to open a new one. The ties between Hispanic America and Spain had weakened even further, despite the end of the British attacks, now that the mother country was directly affected by the war. Britain, with its maritime hegemony, could call into question the Spanish trade system from the vantage point of a crucial ally.

Although Spanish America would gradually open up to direct trade with Britain since 1808, in general colonial officials used licenses to merchants from the newly allied nation and a notgeneralized tolerance of contraband as tools to stress the principle that direct trade with Great Britain was to be regarded as an exceptional fact linked to a new phase of the war in Europe. Independence alone would change that.

Admiral William Sidney Smith (1764-1840), head of the British naval station in Rio de Janeiro, immediately proposed to Liniers an anti-French alliance, which was accepted. The Portuguese pressed to invade the Spanish viceroyalty from Brazil on the pretext of securing Buenos Aires for the anti-French alliance, and British officers on the spot had initially almost been enticed into supporting the initiative. ${ }^{34}$ Britain envisaged concluding a trade agreement with anti-French Spain in the near future, and therefore did not intend to negotiate the formal opening of the port with Liniers. ${ }^{35}$ British protection against the remote possibility of a French attack on Río de la Plata came with threats of retaliation, however veiled, in the event that Liniers should order seizures of British properties. Smith wrote to Liniers, in connection with an episode that had taken place elsewhere in South America:

Quel malheur, si on était réduit à faire des représailles pour recouvrir un equivalent au valoir si injustement enlevé des propriétaires! ${ }^{36}$

In 1808-1809, at least 41 British armed merchant ships arrived in Río de la Plata, mainly from Rio de Janeiro, where the Prince Regent of Portugal had previously opened direct trade with Britain. ${ }^{37}$ In May 1809 Liniers wrote to the Seville Junta that, as it was not possible to fend

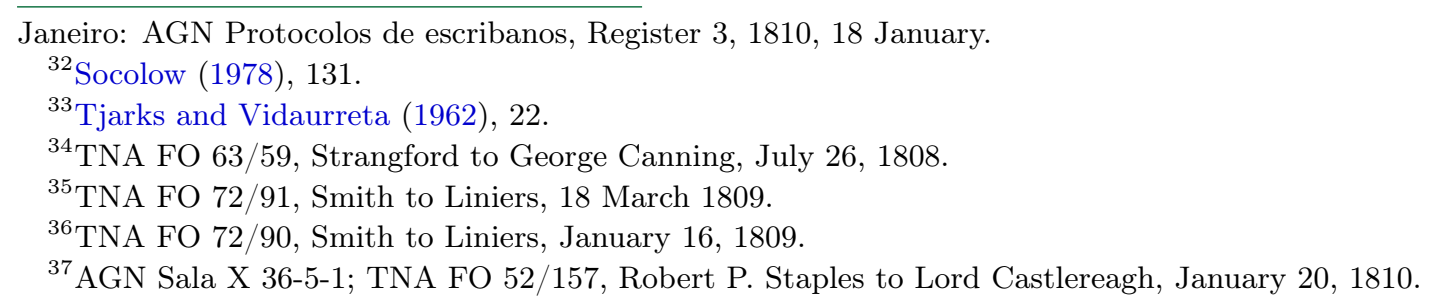


them off by force, he had tried to exploit the new situation as much as possible, by delivering permits to some merchants to import military supplies for the Viceregal government and using this opportunity to replenish the public coffers with customs revenues. ${ }^{38}$

Anita was the woman to turn to when it came to obtaining these kinds of licenses - as well as securing the laxity in smuggling control that accompanied and sometimes replaced them and was opportune in the new context of the alliance with Britain. As one of the British merchants wrote in no ambiguous terms: "She sold her influence on the Government to every one who can pay the price of it." 39 Her central position, both in international merchant networks with key terminal points in Spanish South America, and in viceroyal domestic policy, allowed her to bring together diverging interests. She handpicked which merchants were to be granted, as privileges and favors, the commercial opportunities that the newcomers could have created by threat and violence in any case. On one hand, the Viceroy could not and did not wish to extend such opportunities generally to all the British, as the position of the Seville government on the opening of direct trade was unknown to him, and he had reasons to fear the hostility of the porteño merchant elite to such initiative. On the other hand, neither side wished the unavoidable opening of British direct trade to become the cause of a conflict that could be detrimental to the delicate political balance. Anita's intercession was exercised in exchange for gifts, as emerges from the account of merchant Thomas Kinder (1781-1847), who even mentions a sort of price; i.e., an indicative value of which all parties were aware. ${ }^{40}$

Anita did not just intercede to grant permits to trade legally with Buenos Aires, but was also, according to various testimonies, at the heart of the British smuggling activities (which thus prevented revenues from reaching the treasury). Zachary Macaulay's agent in Montevideo, a British merchant who was critical of Liniers, wrote:

But with all he [Liniers] pays the most marked attention to all the Englishmen in Buenos Aires, [...] [the duties] are now placed in the shape of bribes for the privilege of smuggling to a French Lady who lives with him, and manages the landing of the Cargoes [...], his own revenues derived through this female favourite. ${ }^{41}$

Some members of the Álzaga party denounced to the Spanish government that Liniers tolerated smuggling by British merchants if Anita received a donation of $20 \%$ or $25 \%$ of the value of the cargo. ${ }^{42}$ By means of this system, the port of Buenos Aires was informally open to direct trade with Spain's former archenemy.

Thus, Anita became a decisive mediator in the intricate Atlantic trans-imperial trade system at the time of the Napoleonic Wars. Liniers was using to some extent a traditional means of managing commercial trafficking: granting privileges by a senior official of the Spanish Empire and locally disregarding laws and rules in cases of exceptional gravity. Since he could not, and did not wish to, openly extend such privileges to the many British merchants arriving in Río de

\footnotetext{
${ }^{38}$ González y González (1972), 540. The original document is in AGI, Buenos Aires, 96.

${ }^{39}$ TNA FO 63/85, Graves to Strangford, July 13, 1810.

${ }^{40}$ Newitt (2010), 175, 184. If a gift comes at a price, in diplomatic relations it is traditionally considered a tribute and, in private relations, a form of corruption.

${ }^{41}$ TNA FO 72/90, Macaulay to Canning, August 10, 1809, Annex (italics added).

${ }^{42}$ Tjarks and Vidaurreta (1962), 18.
} 
la Plata at the time, he did so informally and partially through Anita, who was far from passive and indeed personally selected whom to favor. It should not go unnoticed that another informal mediator in these dealings, mentioned in the sources albeit to a lesser extent, was Liniers's brother-in-law, Manuel de Sarratea, who, like Anita, had a history of dealing with British trade networks and acted in Buenos Aires through his employees and as a consignee of the British. Kinder wrote:

To prevent your vessel being ordered out of the harbour, you will likewise have to make a friend of somebody, who has the General [Liniers]'s favour [...] one of whom is Sarratoa [Sarratea] the brother-in-law of Liniers [...]. Under a more cautious conduct, 10,000 [Spanish dollars] presented to Mrs. O'Gorman, in due form, would certainly have obtained him leave to sell. ${ }^{43}$

As a result, direct trade with the British reached unprecedented heights. According to estimates by Kinder and his partner, British government informant Robert Staples, between November 1808 and November 1809, British merchants in Río de la Plata introduced goods for a total value of 1,653,000 pounds - a considerable sum, which for the most part derived, as is clearly explained in these calculations, from smuggling. ${ }^{44}$

Anita's growing personal influence also had political implications, ${ }^{45}$ earning her the enmity of the most important members of local institutions, especially the Cabildo. The Buenos Aires elite never fully accepted Anita, who remained a foreigner even though she was a de facto vicereine. Not even the British merchants saw her as one of their own, despite her Irish marriage and her husband's family and business ties with Britain, which certainly were essential elements of her role as trans-imperial mediator. ${ }^{46}$ As we have seen, some Britons referred to Anita as "a French Lady." Moreover, in a letter of July 1809 to Lord Strangford (1780-1855), the British Ambassador to Brazil, merchant Alexander Graves describes Anita as "a woman who held all observances and obligations of no account, which stood between her and the gratification of her voluptuousness and ambition." Graves also wrote:

\footnotetext{
${ }^{43}$ Newitt (2010), 182-184.

${ }^{44}$ TNA FO $72 / 157$, Staples to Castlereagh, January 20, 1810. On Staples, see my PhD thesis: Besseghini (2016).

${ }^{45}$ For example, during the British invasions White helped the attackers and chose to follow them to Montevideo. Once the second invasion was rejected, however, White enjoyed the protection of Liniers. According to Kinder, who met White during his stay in Buenos Aires, this was because Anita had interceded in his favor. We know that White and Anita had known each other for some time. However, Kinder provided a specific explanation for the favor bestowed on the American: the conspicuous gifts. "W[hite] being supposed to have gratified her with presents to the amount of at least 30,000 dollars, \& in consequence [...] he enjoys commercial advantages beyond every other man." Newitt (2010), 175.

${ }^{46}$ The role of trans-imperial mediators has been studied, for example, by Natalie Rothman, in the context of commercial and political relations between Venice and the Ottoman Empire in the 16th and 17th centuries (Rothman, 2012). Anita's case may also be useful to overcome some problems in linking micro-history and global history (De Vito and Franzinetti, 2015). The research proposal of which this paper is a part is to study not just a given biographical trajectory or transactional network, but precisely those characters, like Anita, placed in such a position as to be able to influence significantly political and economic dynamics of global interest, and whose stories can shed light on local initiatives and practices otherwise neglected by the greater history.
} 
[Anita] exercised almost unbounded sway over him [Liniers]. She filled many public situations with her unprincipled acquaintances [...]. This open undisguised flagitiousness gave great offence to all the better classes of the people, and as they saw also that it was very much through her ascendency over the Viceroy, that the vicious and the profligate were promoted to rank and employments, $[\ldots]$ they regarded her as one of their greatest enemies, at the same time that they held her in contempt, as a woman equally destitute of virtue and of decency. ${ }^{47}$

During the forced absence of the sovereign considered legitimate (the so-called acefalia del imperio), the power of the viceroys, which depended directly on the king, was sometimes weakened throughout the Spanish territories. In the absence of opportune negotiations, Álzaga's group in the Cabildo of Buenos Aires unleashed a particularly bitter clash with Liniers, who had not been able to constrain the conduct, regarded as corrupt, of his protégés within acceptable limits. Moreover, he was an immigrant of French descent, too closely related to other French immigrants (such as the Périchons) and supported only hesitantly by the very weak antiFrench government of Seville. The marriage of his daughter, María del Carmen de Liniers y Sarratea, to Anita's brother, Jean Périchon, celebrated on December 26, 1808, was a politically risky move. Suspicions began to arise within the porteño elite about intentions of establishing a French Périchon-Liniers dynasty in Buenos Aires. Moreover, this union was irregular, because the Viceroy's family members could not marry without permission. The Cabildo denounced the marriage before the Audiencia ${ }^{48}$ and Álzaga led a revolt against the Viceroy in January 1809. The role of Colonel Cornelio Saavedra (1759-1829), from the so-called Creole Party, in foiling the uprising subsequently gained him great influence. ${ }^{49}$ Álzaga was sentenced to deportation, but was saved by the governor of Montevideo, Francisco Javier Elío (1767-1822), who in September, shortly after the arrival of news about the creation of the anti-French Juntas in Spain, had proclaimed the autonomy of Montevideo in the name of Ferdinand VII. Elío also sought to attract British merchant ships to Montevideo. At the beginning of 1809, Liniers reacted with a maritime blockade of the rival city, which was frustrated by the presence of the British Navy. ${ }^{50}$

Zachary Macaulay then wrote to Foreign Secretary George Canning that weapons were necessary to defend Montevideo against possible attacks by Liniers, as Elío believed that the news of the first defeats of the anti-French forces in Spain would induce the Viceroy "to throw off the mask and to attempt securyng this viceroyalty for Joseph Bonaparte." ${ }^{51}$ It was believed that Liniers preferred to tolerate smuggling rather than permit general direct trade with Great Britain to allow people who were very close to him, especially Anita, to pocket the gifts and bribes of merchants, thus to strengthen their power in view of some political coup. Macaulay's agent in Montevideo had even arranged an expedition to the Cape of Good Hope to buy weapons to be sold in Montevideo for its defense. ${ }^{52}$ However, a shipment of weapons from the Cape was held in Rio de Janeiro by British Ambassador Strangford in order to prevent Liniers from using its

\footnotetext{
${ }^{47}$ TNA FO 63/85, Graves to Strangford, July 13, 1810.

${ }^{48}$ Mayo Documental, Vol. V, 119.

${ }^{49}$ For a concise description of these events see, for example, Johnson (2011), 270.

${ }^{50}$ Tjarks and Vidaurreta (1962), 16-19; TNA FO 72/91, Smith to Liniers, 18 March 1809; ADM 1/19 Smith to De Courcy, 24 May 1809.

${ }^{51}$ TNA FO 72/90, Macaulay to Canning, August 10, 1809.

${ }^{52}$ Ibid.
} 
delivery to Montevideo as an excuse to act against the interests of British merchants in Buenos Aires. $^{53}$

The dispatches from Latin America and Spain by James Burke, a French-Irish secret agent in the service of the British government, helped to further fuel British suspicions as to Liniers's loyalty to the anti-French coalition. ${ }^{54}$ At least since the time of his first mission to Buenos Aires in 1804, during which he even passed himself off as a Prussian, Burke had known Thomas O'Gorman and his wife Anita, with whom, according to a romanticized version of the facts, he was then having an affair. ${ }^{55}$ In 1808, the War Secretary, Lord Castlereagh, decided to send Burke back to Río de la Plata with the task of communicating "to the people of that Country" that Britain's main purpose was to garrison the region against France, but that if Spain fell entirely into French hands, then it would be desirable that Hispanic America became independent. ${ }^{56}$ Burke managed to accomplish this part of the mission in 1809, speaking with some "friends of independence" at the port, but was unable to establish useful contact with Liniers. The Viceroy, in fact, publicly exposed him as the man who had lied about his identity a few years earlier and had him immediately shipped back to Rio de Janeiro. ${ }^{57}$ Burke, however, had another mission on behalf of Carlota Joaquina of Bourbon, wife of the Prince Regent of Portugal, sister of the deposed King of Spain, and candidate to become regent of Hispanic America with the support of Admiral Sidney Smith: ${ }^{58}$ distancing Anita from Liniers. According to Burke's writings, Carlota was convinced that Anita would induce Liniers not to agree to hand over power to another Viceroy or to herself as regent. Burke later claimed that he had managed to remove Anita from Buenos Aires thanks to a letter to Liniers, whose content is unknown. ${ }^{59}$ The lady was then sent to Rio de Janeiro, where she apparently became the mistress of Ambassador Strangford. ${ }^{60}$

In July 1809, Baltasar de Cisneros (1756-1829) replaced Liniers as Viceroy, following many requests to the Seville Junta, including those of Princess Carlota and Elío. Even the Buenos Aires Audiencia had requested the removal of Liniers. Its members did not share Elío's suspicions about him, mostly linked to his French origin; but the initiatives of Álzaga and Elío, although explicitly aimed only at Liniers and theoretically implemented to protect the Spanish monarchy, instead seriously called into question the relationship between the mother country and Hispanic American

\footnotetext{
${ }^{53}$ Tjarks and Vidaurreta (1962), 21. Merchant William Dunn's version of the facts seems to refute Macaulay's testimony. In July 1809, he wrote in Rio de Janeiro that Liniers was on the verge of officially opening direct trade with Great Britain. However, Strangford interpreted this promise as an attempt by Liniers to gain British support for the planned resistance against his replacement. Halperín (1972), 37; TNA FO 72/90, Dunn to Alexander Cunningham, July 15, 1809; Strangford to Canning, August 16, 1809.

${ }^{54}$ TNA FO $72 / 81$.

${ }^{55}$ Roberts (1938), 38, 54-55. TNA FO 72/92, Smith to Castlereagh, April 8, 1809. In popular culture, the idea of a relationship between Anita and Burke is mentioned, for example in Tom Williams's fictionalized story about James Burke (the episode entitled Burke in the Land of Silver).

${ }^{56}$ TNA FO 72/91, Castlereagh to Burke, August 4, 1808; Castlereagh to Smith, August 4, 1808.

${ }^{57}$ TNA FO 72/81, Narrative of Col. Burke. See also: TNA ADM 1/19, Liniers to Smith, 13 April 1809.

${ }^{58}$ Ternavasio (2015).

${ }^{59}$ TNA FO 72/81, Narrative of Col. Burke. Roberts (1938), 358; El Clarín, October 25, 2016.

${ }^{60}$ TNA FO 65/85, Graves to Strangford, July 13, 1810. Anita was referred to as the mistress of an Englishman with an important assignment in Rio de Janeiro, who was supposed to be destined as a soon-to-be appointed British agent in Buenos Aires. The allusive tone of the letter suggests that it may be Strangford himself, as reported in the popular version of Anita's story.
} 
territories. In fact, they were examples of insubordination towards the highest hierarchies of the colonial administration and were de facto experiments of autonomous government that added to those of the first Junta-based revolutions within the viceroyalty. It was therefore necessary to appoint a Spanish Viceroy to strip the autonomy supporters of a pretext (i.e., the suspected betrayal of Liniers in favor of Bonaparte) that was fueling the spread of such practices in Río de la Plata. ${ }^{61}$ It is worth recalling that Mariano Moreno, one of the main ideologists of a radical and centralist reading of the autonomous government experience that would soon begin in Buenos Aires, was a member of Álzaga's party. ${ }^{62}$ However, the latter and Elío, although rebellious against Liniers, were later opponents of the Buenos Aires Junta and allies of Cisneros, the last Viceroy.

On November 6, 1809, Cisneros finally legalized direct trade with Britain, although it was subject to rather restrictive rules. The British found themselves almost nostalgic for the wider possibilities provided by Liniers's tolerated smuggling regime. In fact, they could no longer reside, own warehouses, houses or land, or establish companies in Buenos Aires; and their silver exports were severely limited. ${ }^{63}$ The system of corruption centered around Anita in particular had fueled suspicions against Liniers; but the liberalization of direct trade had even worse results for the Spanish monarchy, as it produced general discontent, generating both protests by a fraction of the merchant elite and the establishment of regulations with which the British merchants felt they could not comply. For this reason, and contradicting his initial promises of tolerance, Cisneros decreed the expulsion of the many British merchants suspected of contraband, which was to become effective, after several delays, on May 26, $1810 .{ }^{64}$ Staples later wrote to Castlereagh, alluding to a possible Spanish boost and direction:

The measures of the Viceroy Cisneros [...] soon became very unpopular, they were directed by the old Spaniards, whose principal aim was to exclude all foreigners, and keep the creoles in subjection. ${ }^{65}$

Yet, on May 25, with the news of the French conquest of Seville, after a Cabildo Abierto led by former supporters of Princess Carlota - such as Juan José Castelli (1764-1812), leader of the party considered by Burke to be the most pro-British ${ }^{66}$ - Viceroy Cisneros was deposed and a Junta took over the government in the name of Ferdinand VII. This action began the process that would lead to Argentina's independence from Spain. Kinder was probably repeating widespread opinion when he wrote that "Cisneros demonstrated the greatest jealousy and dislike of the English." 67

\footnotetext{
${ }^{61}$ Gandia (1954), 281.

${ }^{62}$ On the morenistas see Ternavasio (2009), 77-80.

${ }^{63}$ TNA FO 72/90, Mackinnon to Canning, December 10, 1809; Public Record Office of Northern Ireland [hereafter PRONI] D1567/F/1/5, Staples to Montgomery, Staples \& Co, November 26, 1809.

${ }^{64}$ TNA FO 63/85, Delegation of British merchants to Lord Strangford, September 9, 1810, Annex. TNA FO 72/107, Alexander Mackinnon to Canning, 12 August 1810; TNA FO 72/157, Staples to Castlereagh, June 2, 1810.

${ }^{65}$ TNA FO 72/157, Staples to Castlereagh, June 22, 1812. Annex.

${ }^{66}$ TNA FO 72/81, Burke to Lord Liverpool, November 25, 1809.

${ }^{67}$ Newitt (2010), 208.
} 
In August 1810, Castelli ordered the execution of former Viceroy Liniers, who, having remained loyal to the anti-French government in Cádiz, had been organizing resistance against the Buenos Aires Junta in Cordoba. Álzaga suffered the same fate two years later.

During Cisneros's rule, Anita's home in Rio de Janeiro became a landmark for exiled rioplatenses. Notwithstanding this, when she returned to Buenos Aires in 1810, after the May Revolution and the establishment of the Junta, she was only permitted to disembark thanks to the intercession of British Captain Robert Ramsay, after promising that she would retire to the countryside, away from public affairs. ${ }^{68}$ However, she cultivated the friendship of several Britons, including the Robertson brothers, authors of a famous account about life in Buenos Aires in those years. ${ }^{69}$ Little is known about the fate of Thomas O'Gorman. All we know is that in 1818 Anita declared herself a widow. ${ }^{70}$

Analyzing the case of Anne Périchon to assess the role of corruption as a vector of economic globalization is also useful in highlighting a neglected aspect of the 1808 crisis in Río de la Plata. Ruling the Spanish Empire traditionally meant relying on the pragmatism of local officials. Faced with British supremacy of the seas and the new alliance with Great Britain against "the usurper" in Spain, they found themselves in a position where they could not forcefully ward off British trade, even if they had wanted to. The solutions were different from case to case, complex, and contradictory. A generalized opening of direct trade between the colonies and Great Britain seemed to have been on the table since the early days of the alliance between Great Britain and anti-French Spain, but never materialized. ${ }^{71}$ However, on the local level, some form of legalization of, or tolerance for, British trade was now inevitable.

It is possible to assume that Liniers's informal policy in the face of British pressure to open direct trade with Buenos Aires was in line with tradition. His practice of derogating rules in exceptional circumstances was certainly not new in the Spanish empire, where the motto "acato pero no cumplo" has become paradigmatic of the 'colonial pact' between local officials, the elite, and Madrid. Even influence trafficking by Anne Périchon may be seen as an effective practical solution that brought advantages to different stakeholders. However, in the context of the acefalia del imperio, the central and decisive role of high officials was no longer directly linked to the favor of the king, or his trust in their good offices, even if they might keep their positions in expectation for his return. Thus, Liniers's power was now weaker and could be called into question. The perception, fueled by Álzaga's party, of an openly corrupt system endorsed by Liniers for non-transparent personal and political reasons, and compounded by suspicions of a possible betrayal associated with the French origin of the Viceroy and his mistress, contributed to seriously injuring the monarchy.

The breakdown of the relationship of trust with part of the elite is also explained in light of the dimensions the phenomenon of tolerated smuggling had acquired, which in 1808, thanks to the alliance with Britain and the opening to direct trade in nearby Rio de Janeiro, had reached truly impressive proportions. However, as Liniers himself testified, the massive presence

\footnotetext{
${ }^{68}$ Cremonte (2010), 256-57.

${ }^{69}$ Robertson and Robertson (1843), 159-60.

${ }^{70}$ AGN, Protocolos de escribanos, Register 4, 1818.

${ }^{71}$ Humphreys (1965), 153.
} 
of British merchants, the alliance with London in the war against France, and the uncertainty about Seville's willingness to open direct trade with Britain, made it extremely difficult to choose a course of action. The safest solution for Liniers, pending further developments, was to grant licenses in a sufficiently limited number and in such a way as not to attract criticism from the government in Seville and the Buenos Aires merchant elite, as well as to tolerate smuggling. The latter could not be effectively countered and did not generate direct customs revenues. The gifts to Anita can therefore be interpreted as a means whereby the Viceroy - who, according to various reports, had access to the funds derived from this activity - obtained a sort of voluntary duty whose value tended to converge towards a uniform price to be paid for inducing control negligence. How much revenue this activity generated and how Anita or Liniers invested it, in Buenos Aires or in Rio de Janeiro, and for what political or other purposes, is not known and could be the subject of further research.

The opening of direct trade with Britain in the form of personal favors to British merchants in Buenos Aires was perhaps the most natural reaction to the crisis of the Spanish monarchy and the new position of the Spanish colonies in the global war. It was an attempt to buy time and understand possible developments in an unprecedented situation. In the short period during which Anita was an unofficial vicereine, Río de la Plata de facto opened up to direct trade with Britain, to a significant extent directly through her. Not being able to stop the processes in progress, it was a matter of filtering and trying to control the impact on rioplatense society of the economic and political power of British merchants and their networks through personal relationships cemented by the exchange of favors. Our interpretation is that, in the absence of other appropriate instruments to manage a completely new situation, informal trade became a tool for reacting immediately to an exceptional concentration of pressures to further open up Hispanic America to the world, in the highly uncertain context of the first months of the acefalia del imperio, when all kinds of developments were possible.

For less than a year, this power was in the hands of Anita Périchon, who deserves to be remembered not just as a sort of "Mata Hari of South America"72 for her love affairs and the political intrigues in which she was involved, but also, and above all, as a crucial mediator between temporarily allied imperial interests.

${ }^{72}$ La Nación, March 15, 1998. 


\section{Bibliography}

Besseghini, D. (2016). Commercio britannico e imperialismo informale. Robert P. Staples tra Río de la Plata, Perù e Messico (1808-1824). Phd. Dissertation, Trieste: Università degli Studi di Trieste.

Braudel, F. (1979). Civilisation materielle, economie et capitalism, Vol. 2. Paris: A. Colin.

Brilli, C. (2016). Genoese Trade and Migration in the Spanish Atlantic, 1700-1830. New York and Cambridge: Cambridge University Press.

Brown, J. C. (1987). Decline and Fall of the Spanish Merchants at Buenos Aires: Marco del Pont in the Age of Independence. Texas Papers on Latin America: Pre-Publishing working papers. University of Texas at Austin.

Buist, M. (1974). At Spes non Fracta. Hope \&6 Co. 1770-1815. Den Haag: Springer.

Contreras Carranza, C. (2013). Quiroz, Alfonso W. Historia de la corrupción en el Perú. Translation by Javier Flores Espinoza. Lima: Instituto de Estudios Peruanos e Instituto de Defensa Legal, 2013. 615 pp, Economía 36(72), 212-214.

Cooney, J. (1986). Neutral Vessels and Platine Slavers: Building a Viceregal Merchant Marine. Journal of Latin American Studies 18(1), 25-39.

Cooney, J. (1989). Oceanic commerce and Platine Merchants, 1796-1806: The Challenge of War. The Americas 45(4), 509-524.

Cooney, J. (2004). Commerce, Contraband and Intrigue: Thomas O'Gorman in the Río de la Plata, 1797-1806. Colonial Latin American Historical Review 13(1), 31-51.

Cremonte, N. (2010). La Gazeta de Buenos-Ayres de 1810: luces y sombras de la ilustración revolucionaria. Universidad Nacional de La Plata.

Cuenca-Esteban, J. (2014). British 'Ghost' Exports, American Middlemen and the Trade to Spanish America, 1790-1819: A Speculative Reconstruction. William and Mary Quarterly 71(1), 63-98.

De Vito, C., and Franzinetti, G. (2015). Forum: Microstoria e storia globale, presentations by Christian G. De Vito and Guido Franzinetti. Quaderni storici 150(3), 813-872.

Fannin, T. (2018). Paisanos: The Irish and the Liberation of Latin America. New York: University of Notre Dame Press. Originally published in 2016.

Gallo, K. (2004). Las invasiones inglesas. Buenos Aires: Eudeba.

Galmarini, H. (1980). Comercio y burocracia colonial. A propósito de Tomás Antonio Romero. Investigaciones y ensayos 28-29, 407-439/387-424.

Gandia, E. (1954). Antecedentes de los sucesos de mayo de 1810 en Buenos Aires: el juicio de la audiencia. Revista de Historia de América 37-38, 277-294.

González Climent, A., and González Climent, A. (1972). Historia de la marina mercante argentina. Buenos Aires: s.n.

Grainger, J. (2015). The British Campaigns in the South Atlantic 1805-1807. Barnsley: Pen \& Sword.

Halperín Donghi, T. (1972). Argentina: de la revolución de independencia a la confederación rosista. Buenos Aires: Editorial Paidós.

Heredia, E. (1986). Cuando Sarratea se hizo revolucionario. Buenos Aires: Plus Ultra. 
Hughes, B. (2013). The British Invasions of the River Plate 1806-180\%. Barnsley: Pen and Sword.

Humphreys, R. (1965). British Merchants and South American Independence. Proceeding of the British Academy 51, 151-174.

Jiménez Codinach, G. (1988). Veracruz, almacén de plata en el Atlántico. La Casa Gordon y Murphy, 1805-1824. Historia Mexicana 38(2), 325-353.

Johnson, L. (2011). Workshop of Revolution: Plebeian Buenos Aires and the Atlantic World, 1776-1810. Durham and London: Duke University Press.

Marichal, C. (2007). Bankruptcy of Empire: Mexican Silver and the Wars between Spain, Britain and France, 1760-1810. New York and Cambridge: Cambridge University Press.

Méndez Avellaneda, J. (2008). Las convictas de la Lady Shore. Buenos Aires: Dunken.

Mitre, B. (1887) Historia de Belgrano y de la independencia argentina. Buenos Aires: F. Lajouane. Originally published in 1857.

Newitt, M. (2010). War, Revolution and Society in the Rio de la Plata, 1808-1810: Thomas Kinder's narrative of a Journal to Madeira, Montevideo and Buenos Aires. Oxford: Signal.

Paquette, G. (2011). Visiones británicas del Mundo Atlántico español, c. 1740-1830. Cuadernos de Historia Moderna 36, 145-154.

Pearce, A. (2007). British Trade with Spanish America, 1763-1808. Liverpool: Liverpool University Press.

Pearce, A. (2009). The Hope-Barings Contract: Finance and Trade between Europe and the Americas, 1805-1808. The English Historical Review 124(511), 1324-1352.

Roberts, C. (1938). Las invasiones inglesas del Río de la Plata (1806-1807). Buenos Aires: Talleres Gráficos.

Robertson, J. P., and Robertson, W. P. (1843). Letters from South America: Comprising Travels on the Banks of the Paraná and Rio de la Plata, Vol. 2. London: John Murray.

Rothman, E. N. (2012). Brokering Empire: Trans-Imperial subjects between Venice and Istanbul. Ithaca and London: Cornell University Press.

Silberling, N. J. (1919). British Financial Experience 1790-1830. The Review of Economics and Statistics 1(4), 282-297.

Socolow, S. (1978). The Merchants of Buenos Aires, 1778-1810. Family and Commerce. Cambridge: Cambridge University Press.

Socolow, S. (2007). CLAH Luncheon Address: History and the Goddess Fortune: The Case of Santiago de Liniers. The Americas 64(1), 1-9.

Stein, B. and Stein, S. (2009). Edge of Crisis: War and Trade in the Spanish Atlantic, 1789-1808. Baltimore and London, The John Hopkins University Press.

Ternavasio, M. (2009). Historia de la Argentina, 1806-1852. Buenos Aires: Siglo Ventiuno.

Ternavasio, M. (2015). Candidata a la corona: la infanta Carlota Joaquina en el laberinto de las revoluciones hispanoamericanas. Buenos Aires: Siglo Ventiuno.

Tjarks, G. and Vidaurreta, A. (1962). El comercio inglés y el contrabando: Nuevos aspectos en el estudio de la política económica en el Río de la Plata, 1807-1810. Buenos Aires, Establecimiento gráfico de J. Héctor Matera. 